\title{
Establishment of a Bovine Herpesvirus 4 based vector expressing a secreted form of the Bovine Viral Diarrhoea Virus structural glycoprotein E2 for immunization purposes
} Gaetano Donofrio*1, Chiara Sartori ${ }^{1}$, Lara Ravanetti ${ }^{1}$, Sandro Cavirani1 Laurent Gillet ${ }^{2}$, Alain Vanderplasschen ${ }^{2}$, Simone Taddei ${ }^{1}$ and Cesidio Filippo Flammini ${ }^{1}$

Address: ${ }^{1}$ Università di Parma, Facoltà di Medicina Veterinaria, Dipartimento di Salute Animale, Sezione di Malattie Infettive degli Animali, via del Taglio 8, 43100 Parma, Italy and 2Immunology-Vaccinology, B43 b Faculty of Veterinary Medicine, Boulevard de Colonster 20, University of Liège, B-4000 Liège, Belgium

Email: Gaetano Donofrio* - gaetano.donofrio@unipr.it; Chiara Sartori - chiara.sartori@bbsrc.ac.uk;

Lara Ravanetti - lara.ravanetti@nemo.unipr.it; Sandro Cavirani - sandro.cavirani@unipr.it; Laurent Gillet - lg326@mole.bio.cam.ac.uk;

Alain Vanderplasschen - A.vdplasschen@ulg.ac.be; Simone Taddei - simone.taddei@unipr.it;

Cesidio Filippo Flammini - cesidiofilippo.flammini@unipr.it

* Corresponding author

Published: 18 October 2007

BMC Biotechnology 2007, 7:68 doi:10.1 186/1472-6750-7-68

This article is available from: http://www.biomedcentral.com/I472-6750/7/68

(C) 2007 Donofrio et al; licensee BioMed Central Ltd.

This is an Open Access article distributed under the terms of the Creative Commons Attribution License (http://creativecommons.org/licenses/by/2.0), which permits unrestricted use, distribution, and reproduction in any medium, provided the original work is properly cited.
Received: 10 May 2007

Accepted: 18 October 2007

\begin{abstract}
Background: The biological characteristics of BoHV-4 make it a good candidate as a gene delivery vector for vaccination purposes. These characteristics include little or no pathogenicity, unlikely oncogenicity, the capability to accommodate large amounts of foreign genetic material, the ability to infect several cell types from different animal species, and the ability to maintain transgene expression in both undifferentiated and differentiated cells.
\end{abstract}

Results: A recombinant bovine herpesvirus 4 (BoHV-4CMV-IgKE2-I4 $\Delta$ TK) expressing an enhanced secreted form of the bovine viral diarrhea virus (BVDV) structural glycoprotein E2 (gE214), obtained by the removal of the putative transmembrane domain and addition of a 14 amino acids peptide at its carboxyl terminal and an immunoglobulin $K$ signal peptide to the amino terminal, was successfully constructed using a Recombineering (recombination -mediated genetic engineering) approach on BoHV-4 cloned as bacterial artificial chromosome. The galactokinase based recombineering system was modified by the introduction of a kanamycin expression cassette and a kanamycin selection step that allowed a significant reduction of the untargeted background clones. BoHV-4CMV-IgKE2-I4ATK infected cell lines highly expressed gE2-14, which maintained native antigenic properties in a serum neutralization inhibition test. When rabbits and sheep were immunized with BoHV-4CMV-IgKE2-I4 $\Delta T K$, high levels of serum neutralized antibodies against BVDV were generated.

Conclusion: This work highlights the engineerization of BoHV-4 genome as a vector for vaccine purposes and may provide the basis for BVDV vaccination exploiting the BoHV-4- based vector that delivers an improved secreted version of the BVDV structural glycoprotein E2. 


\section{Background}

Bovine herpesvirus 4 (BoHV-4) has been isolated from a variety of samples and cells from healthy cattle and from cattle that have experienced abortion or affected by metritis, pneumonia, diarrhoea, respiratory infection, and mammary pustular dermatitis [1]. The virus was first isolated in Europe from cattle with respiratory and ocular diseases by Bartha et al. [2] and later in the United States by Mohanty et al. [3]. Subsequently, distinct BoHV-4 isolates were obtained both in Europe and in the United States [1,4-6]. However, the pathogenic role of BoHV-4 remains unclear and despite its tropism for bovine endometrial cells [7], experimental disease has been reproduced by only a limited number of investigators [8]. BoHV-4 is classified as a gammaherpesvirus based on genome sequence and differs from other Gammaherpesviridae members in important biological properties [9-11]. Unlike most other gammaherpesviruses, BoHV-4 causes a cytopathiceffect (CPE) and replicates in a variety of primary cultures and cell lines of bovine and various other animal species [12]. In addition, there is no evidence for oncogenicity or growthtransformation by BoHV-4.

In contrast to BoHV-4, bovine viral diarrhoea virus (BVDV) is a pestivirus considered to be one of the major viral pathogens of cattle and causes significant economic losses worldwide [13]. Pestiviruses are classified as a separate genus within the family Flaviviridae, which also includes flaviviruses and the hepatitis $C$ virus group [14]. Currently three pestivirus species are recognized, namely, BVDV, classical swine fever virus, and border disease virus of sheep. The Pestivirus genomes are positive-stranded RNAs, usually of approximately 12,300 nucleotides, which encode polyproteins of around 4,000 amino acids [15]. Entire or partial genomic sequences of numerous BVDV, classical swine fever virus, and border disease virus isolates have been determined $[16,17]$, and their comparison has demonstrated a high degree of sequence conservation among Pestiviruses. The virions of Pestiviruses consist, together with the RNA, of four structural proteins, the nucleocapsid $\mathrm{C}$ protein and the envelope glycoproteins Erns, E1, and E2 [18]. Currently, 11 pestiviral proteins have been identified as products of polyprotein processing, which occurs co- and post-translationally, due to the activity of viral and host cell proteases. In the hypothetical polyprotein, the proteins are arranged in the order Npro/C/Erns/E1/E2/NS2/NS3/NS4A/NS4B/NS5A/NS5B

[19]. The gE2 protein of the BVDV NADL strain consists of about 370 amino acids and has a calculated molecular mass of $41 \mathrm{kDa}$. The $\mathrm{N}$ terminus of BVDV gE2 is formed by Arg-690, and the $\mathrm{C}$ terminusis located around amino acid 1063. The $\mathrm{C}$ terminus of gE2 includesapproximately 30 amino acids, which could function as a transmembraneanchor for gE2, and has a translocation signal for the downstreamprotein. Full-length gE2 remains cell associ- ated in virus-infectedcells [20]. Due to the immunodominant characteristics of BVDV E2 glycoprotein [19], in the present work we explored the feasibility of employing a BoHV-4 - based vector to deliver the BVDV glycoprotein E2 as a secreted form and generated a model for BVDV and other pestiviruses vaccination by BoHV-4 expressing BVDV gE2.

\section{Results \\ Rational design and construction of a plasmid vector expressing BVDV gE2}

We first optimized a suitable expression cassette to achieve a robust expression of gE2 by eukaryotic cells before attempting to express BVDV gE2 in a BoHV-4 based vector. It has been reported that mice and cattle immunized with plasmid encoding a secreted form of gE2 developed significantly higher IgG and virus neutralizing antibody titres compared to animals vaccinated with plasmid encoding a membrane linked gE2 [21]. Two expression cassettes were therefore constructed, pCMV-IgKE2-14 and pCMV-IgKE2-23, expressing the secreted form of gE2. pCMV-IgKE2-14 (Fig. 1a), contained the cytomegalovirus (CMV) promoter, an immunoglobulin $K$ light chain (Igk) leader sequence specifying secretion of heterologous proteins, the gE2 ORF lacking the putative transmembrane domain and a polar hydrophilic (as calculated by Hopp \& Woods method (Hopp \& Woods 1983)) non structured 14-amino-acid peptide (Fig. 1a and 1c), that we hypothesized would increase the secretion of the protein. To test this hypothesis, a second expression cassette, pCMVIgKE2-23, was constructed as a control. The polar hydrophilic 14-amino-acid peptide of pCMV-IgKE2-14 was substituted with a less hydrophilic 23-amino-acid peptide (Fig. 1b and 1d). Next, the translation and secretion of E2 in the culture medium, compared with the fraction retained in the cells, was assessed in transiently transfected HEK 293T cells, by Western blotting. As shown in Fig. 1e, gE2-14 was better secreted into the culture supernatant, compared to gE2-23 that was abundantly retained in the cell fraction. The densitometric quantification of the bands revealed $\sim 10$ fold better secretion of E214 compared to E2-23. CMV-IgKE2-14 was then employed to generate a recombinant BoHV-4.

\section{Site specific targeted integration of IgKE2-I 4 expression cassette into the BoHV-4 based vector genome by GalK system}

The thymidine kinase (TK) gene has been disrupted in several herpesviruses, including BoHV-4, by the insertion of foreign sequences without interfering with viral replication in vitro [22-25]. Furthermore, this genomic region is highly conserved among BoHV-4 isolates [25,26], ensuring the stability of the genomic locus for the insertion of foreign expression cassettes. Therefore, the BoHV-4 TK gene was chosen as a target site for the insertion of CMV- 
a) $\quad$ pCMV-IgK-E2-14
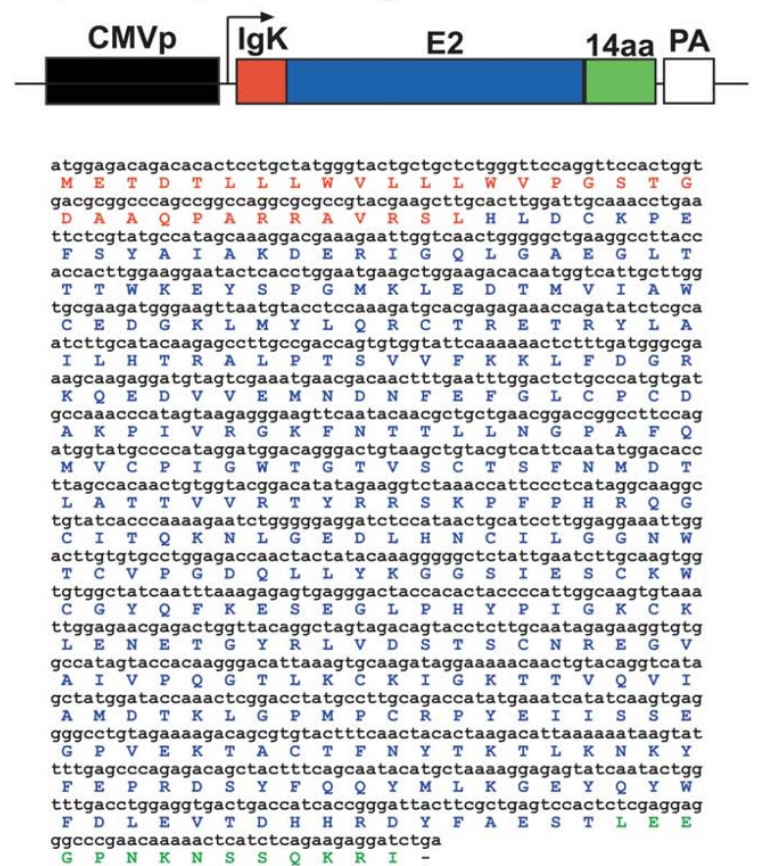

c)

\section{hydrophilicity}

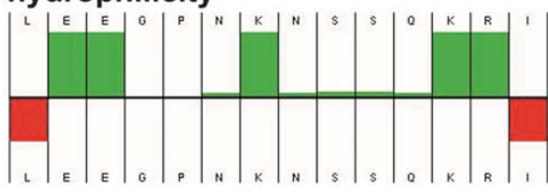

Net charge at $\mathrm{pH} 7.0: 1$

Iso-electric point, pl: 9.9

Average hydrophilicity: 0.9
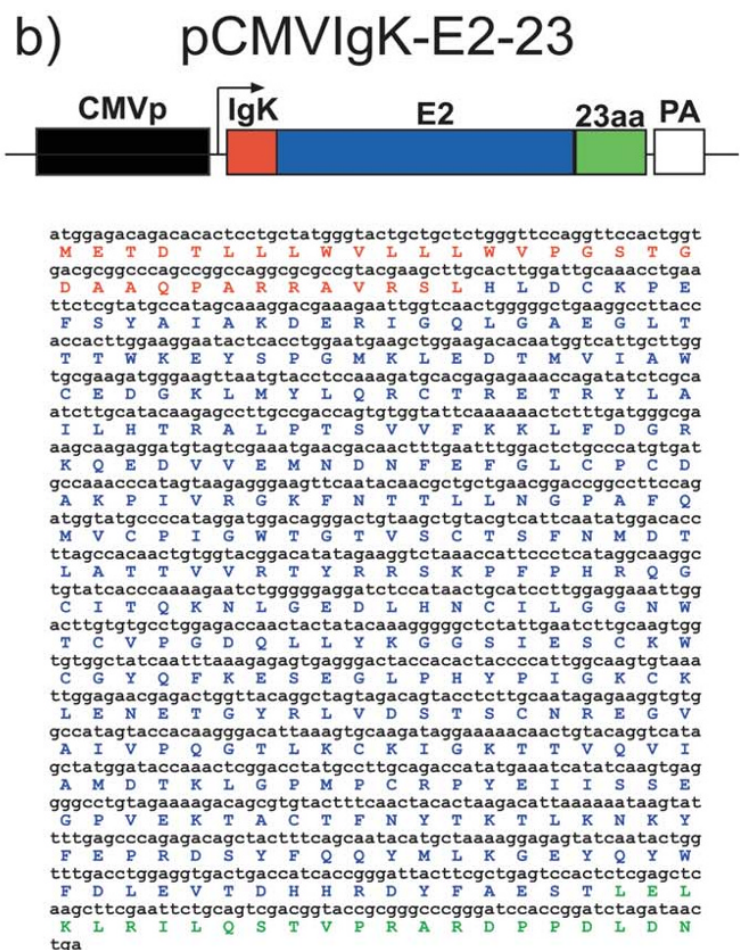

tga

d)

hydrophilicity

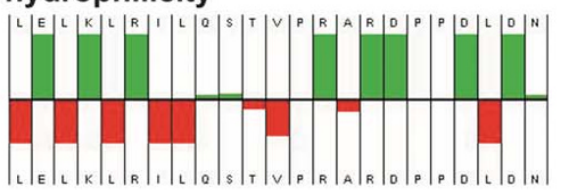

Net charge at $\mathrm{pH} 7.0: 0$

Iso-electric point, $\mathrm{pl}$ : 7.1

Average hydrophilicity: 0.5

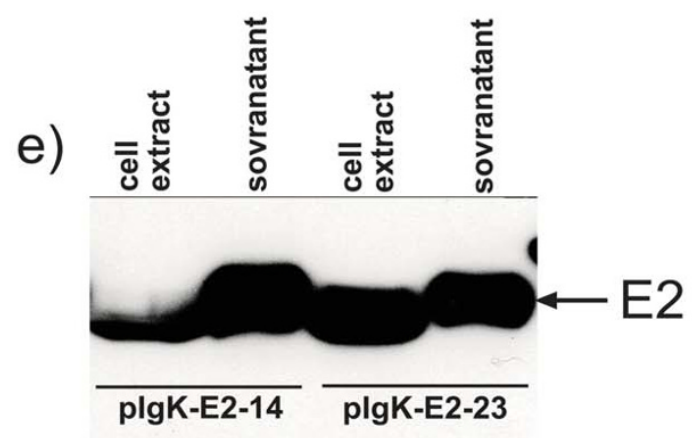

Figure I

Structure and evaluation of plasmid vectors expressing the secreted forms of gE2. a) Diagram (not to scale) showing the PCMV-IgKE2-I 4 vector along with the sequence, and predicted amino-acid product, containing: the CMV enhancer promoter (CMV, in black box), the lgK signal peptide (red box) in frame with the E2 ORF and I4 hydrophilic extra amino acids peptide (I4aa, green box) and the bovine growth hormone polyadenylation signal (PA, white box). b) Diagram (not to scale) showing the PCMV-IgKE2-23 vector along with the sequence and the predicted amino-acid product, containing: the CMV enhancer promoter (black box), the IgK signal peptide (red box) in frame with the E2 ORF and 23 hydrophobic extra amino acids peptide (23aa, green box) and the bovine growth hormone polyadenylation signal (PA, white box). c) Hydrophilicity plot of the 14 aa and 23 aa (in d) peptides with the calculated net charge, iso-electric point and the average hydrophilicity. e) Western immunoblotting of cell extracts and supernatant of cells transfected with plgKE2-I4 and plgKE2-23. 
IgKE2-14 expression cassette to integrate the IgKE2-14 expression cassette into the BoHV-4 genome, cloned as BAC [27]. The BACrecombineering system approach [28], modified by the introduction of a kanamycin selection step, was used for this purpose. Accordingly, the galactokinase cassette $(\mathrm{GalK})$ along with a kanamycin resistance cassette, both under the control of constitutively active prokaryotic promoters, were subcloned in pINT2 [25] to be flanked by the BoHV-4 TK gene and adjacent sequences. The generated targeting vector (TK-KanaGalKTK) (Fig. 2a) was excised out from the plasmid backbone and used for heat-inducible homologous recombination in SW102 E. Coli containing the BAC BoHV-4 genome. Following a positive selection in minimal medium containing galactose (on solid agar plate) and a second positive selection with medium containing kanamycin (liquid medium), all the clones analyzed displayed the correct targeting (Fig. 2b). Thus, the second selection with kanamycin reduced the background to zero. A second targeting vector was generated sub-cloning in pINT2 the CMVIgKE2-14 (TK-CMV-IgKE2-14-TK) and re-targeting was performed to replace the KanaGalK cassette with the CMV-IgKE2-14 cassette (Fig. 2c). Negative selection on DOG minimal plates, following a negative selection with medium containing kanamycin and keeping clones surviving in medium containing chloramphenicol but dieing in medium containing kanamycin, allowed the isolation of clones all positive for the right targeting, without background (Fig. 2c and 2d). Next, the BAC BoHV-4 genome transporting the CMV-IgKE2-14 cassette into the TK locus was transfected in BEK cells expressing the Cre recombinase to remove the $\mathrm{BAC}$ cassette flanked by the lox sequences and to reconstitute the infectious virus (BoHV4CMV-IgKE2-14ATK).

\section{BoHV-4CMV-IgKE2-I4 $\triangle$ TK allows robust expression and secretion of gE2-14 in the supernatant of infected cells} To evaluate gE2-14 expression by the BoHV-4CMV-IgKE2$14 \Delta \mathrm{TK}$ infection, several bovine cell lines, including BEK, stromal, BEND, PEB, MDBK and BoMac cells were acutely infected with 5 m.o.i. of BoHV-4CMV-IgKE2-14ATK; at 6 $\mathrm{h}$ post-infection, the medium was removed, cells were gently washed with serum-free medium to eliminate any trace of serum protein and incubatedfor $72 \mathrm{~h}$ with new serum-free medium. Thus, the only proteins present in the medium were cell-secreted proteins. The medium was analyzed by Western immunoblotting. As shown in Fig. 3a, of gE2-14 expression well detected for all cell lines tested, although high variability was observed among the lines. The highest expression was observed for the stromal cell line, while the MDBK cell line gave the lowest.

The outcome of BoHV-4 infection depended on the cell type: i) persistent infection, as is the case for BoMac cells where, following permissive infection with an extensive
CPE, surviving and replicating cells were found to be persistently infected, maintaining the viral genome over many passages and producing low levels of infectious virus. ìi) permissive infection, characterized by strong CPE and an abundant viral replication and high level of infectious virus production, as observed in BEK cells. ìì) unpermissive infection, observed in the rhabdomyosarcoma cell line (RD-4), where BoHV-4 infected cells produced low levels of early and late viral RNAs, but caused no cytopathic effect.

gE2-14 expression and secretion was assessed for these three types of infection and a time course was performed, sampling the medium at 24,48 and $72 \mathrm{~h}$ post infection. The best expression was observed for persistently infected BoMac cells (Fig. 3b).

\section{gE2- 4 retains native antigenic properties}

The E2 protein plays a major role in virus attachment and entry of BVDV [29]. Furthermore, BVDV E2 is important for the inductionof neutralizing antibodies [15] and protection against BVDV challenge in cattle [30,31]. Therefore, we explored the antigenic properties of gE2-14 expressed and secreted by BoHV-4CMV-IgKE2-14 $\Delta$ TK infected cells, by performing a serum neutralization inhibition test, based on the capability of gE2-14 to reduce or block the activity of neutralizing antibodies against BVDV (Fig. 4a). Four heat-inactivated bovine sera that were positive for virus-neutralizingantibodies against BVDV were selected and incubated with conditioned medium containing gE2-14. Positive and negative controls, as well as virus controls, were included (Fig.4b). Virus suspension containing BVDV NADL was added to each well. After incubation, MDBK cell suspension was added. Viral infectivity and serum-neutralizing activitythrough the cytopathic effect were detected by microscopy and/or crystal violet staining of the cell monolayer. The neutralization antibody titers were expressed as the reciprocal of the final dilution of serum that completely inhibited viral infectivity. A strong reduction of the neutralizing activity of the sera was obtained by the conditioned medium containing gE2-14 (Fig. 4b and 4c). No neutralizing inhibition was observed in the control assay performed with conditioned medium in the absence of gE2-14. These findings allowed us to show that gE2-14 maintains the native antigenic properties of BVDV E2.

\section{BoHV-4CMV-IgKE2-14 $4 T K$ expressing gE2-14 is immunogenic and elicits the production of neutralizing antibodies against BVDV}

After collection of preimmune serum, a group of 3 BVDV serum negative rabbits and a group of 4 BVDV serum negative sheep were intravenouslyinoculated with BoHV4CMV-IgKE2-14 $\Delta$ TK. An identical inoculation was performed 2 weeks later. Blood samples were collected 
a)

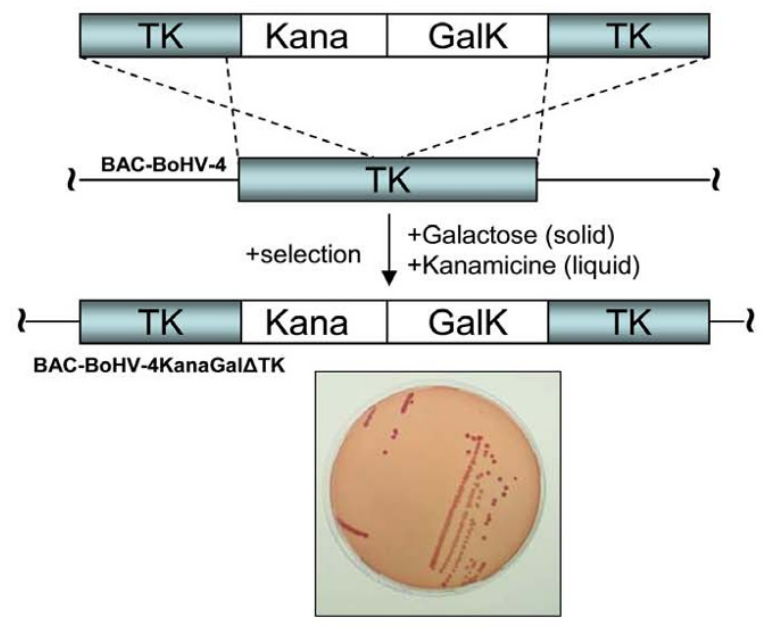

c)

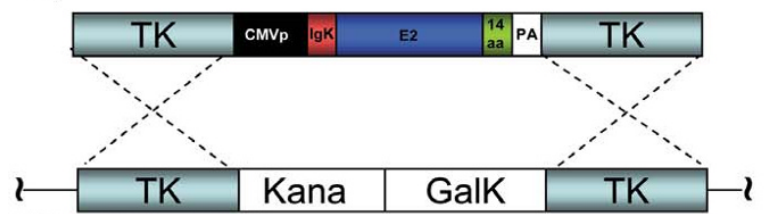

BAC-BoHV-4KanaGaIDTK

-selection

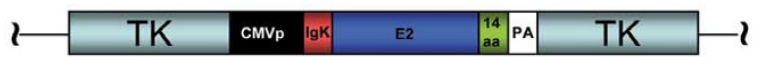

BAC-BoHV-4E2-14ATK
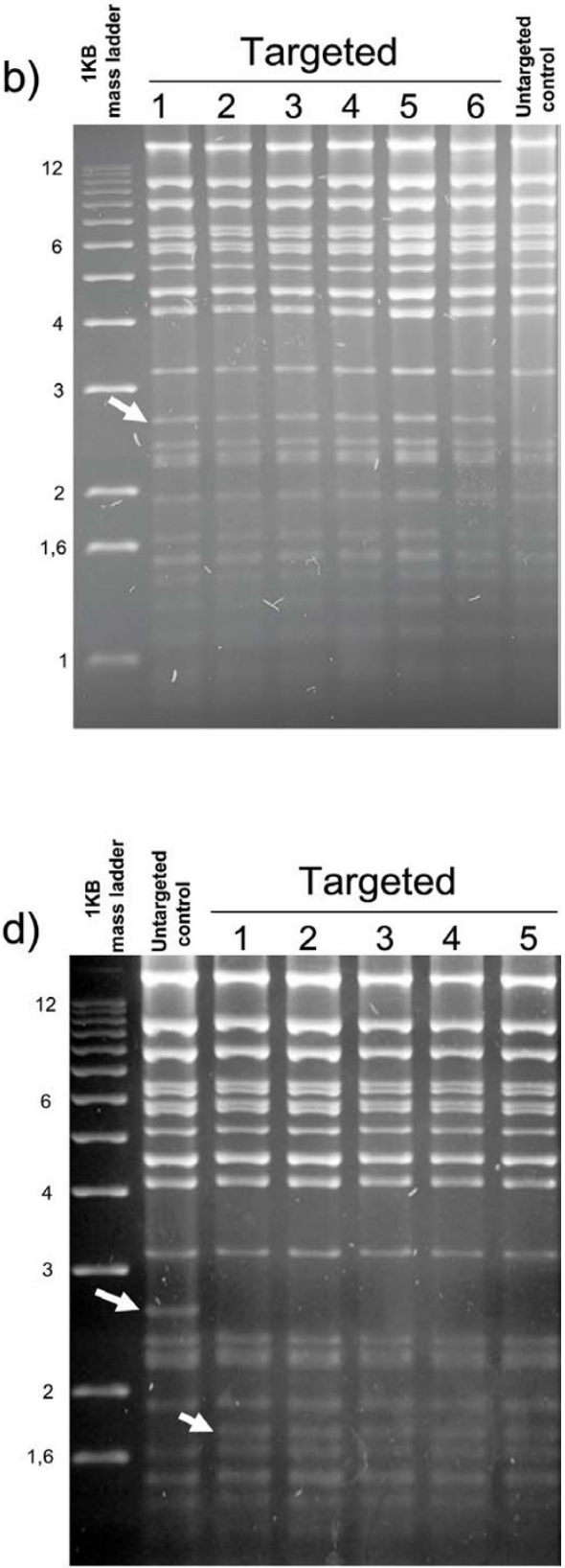

\section{Figure 2}

Overall strategy of BoHV-4CMV-IgKE2-I4 $\Delta$ TK generation. a) First targeting, where kanamycin resistant cassette (Kana) adjacent to the galactokinase cassette (GalK) and flanked by BoHV-4 thymidine Kinase gene and adjacent sequences (TK), are introduced into the TK gene of BoHV-4 genome cloned as bacterial artificial chromosome (BAC-BoHV-4) via heat inducible homologous recombination in SW 102 E. coli. Following a positive selection on (solid) minimal plates containing galactose as the only source of carbon and a positive selection on (liquid) medium containing Kanamycin. Selected clones, fermenting lactose (red colonies) on McConkey plates (representative plate). b) Hindlll restriction enzyme analysis of 6 clones out of hundreds, all displaying the right targeting, where a new $2.6 \mathrm{~kb}$ band (indicated by arrow, I to 6 ) corresponding to the insertion of the Kana/GalK cassettes is present but missing in the untargeted control. c) Second targeting and counter selection, where the Kana/GalK cassettes were removed via heat inducible homologous recombination and replaced with CMV-lgKE2-14 expression cassette. All colonies tested through Hindlll restriction enzyme analysis and agar gel electrophoresis (d) shows the right re-targeting. The disappearing of the $2.6 \mathrm{~kb}$ band and the appearing of a new band with a lower molecular size are indicated by arrows. 
a)
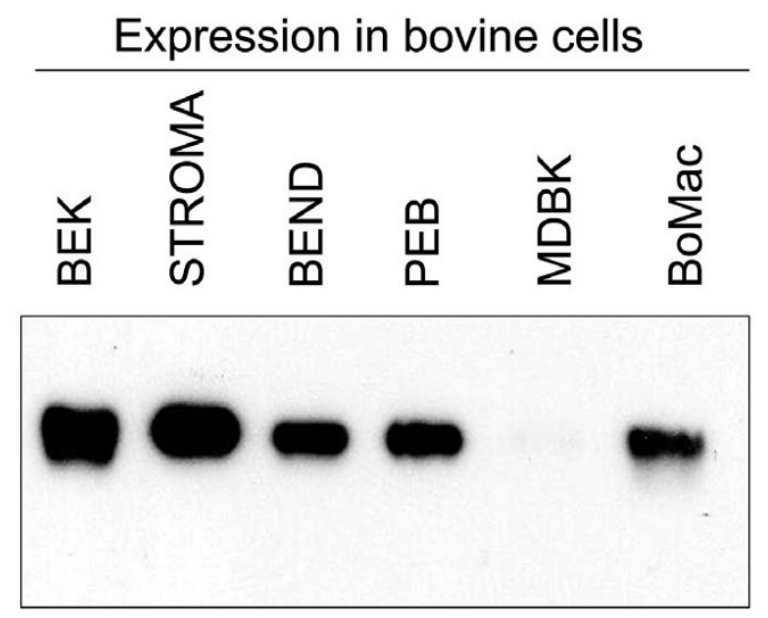

Time P.I.

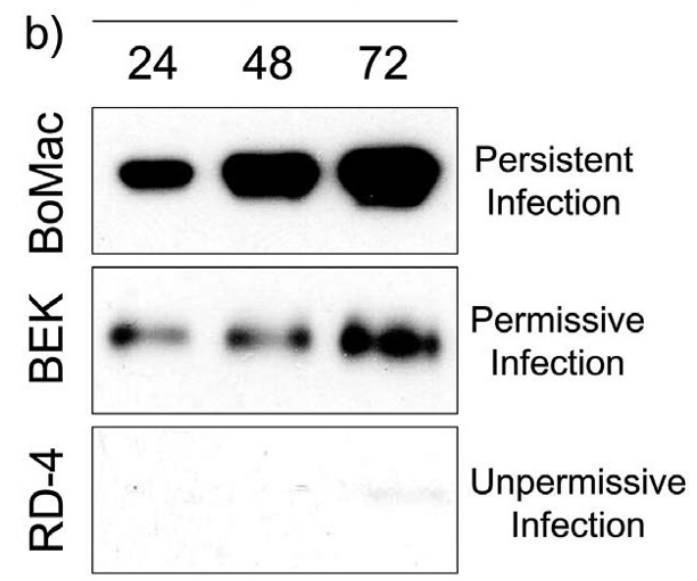

Figure 3

Expression analysis of BoHV-4CMV-IgKE2-I4 $\Delta$ TK infected cell lines. a) Western immunoblotting of supernatant coming from several bovine cell lines infected with BoHV-4CMV-IgKE2-I4ATK. b) Time course of gE2 expression of cells sustaining different types of infection (persistent, permissive and unpermissive infection).

weekly from all animals for the assessment of neutralizing antibodies. Furthermore, body temperature and development of clinical signs were monitored daily. None of the animals developed fever or other clinical signs during the time of observation ( 5 weeks). Both groups of animals developed an antibody response against BVDV, detectable the second week after the first viral inoculation and reaching the plateau phase at the fourth week post-viral inoculation (Fig.5a and 5b). Antibodies were observable 2 weeks following the first viral inoculation and the blood samples were collected before the second viral inoculation. It is therefore possible to conclude that a single inoculation of BoHV-4CMV-IgKE2-14 $\mathrm{TK}$ was able to elicit a a)
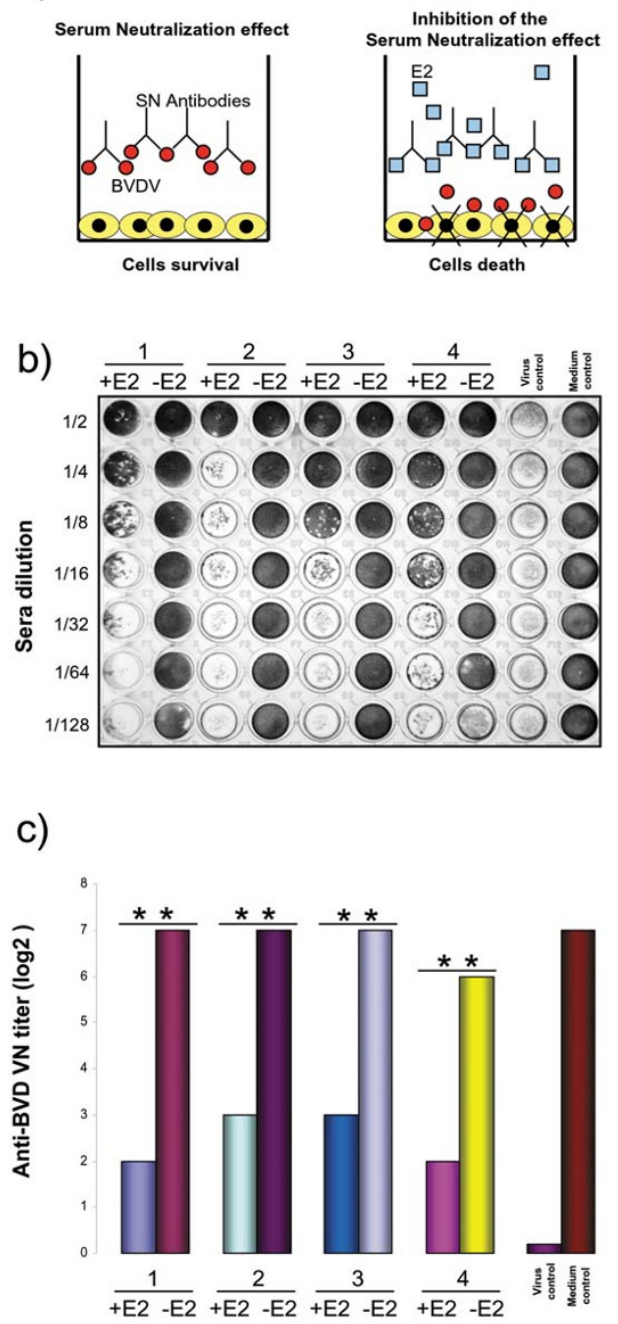

Figure 4

Inhibition of serum neutralization (SN) test, to assay the gE2-I 4 antigenic properties expressed and secreted by BoHV-4CMV-IgKE2-I 4 $\Delta$ TK infected cells. (a) Diagram showing the principle of the assay, where BVDV neutralizing antibodies pre-incubated with medium containing gE2-I4 are blocked, allowing the virus to infect and destroy the cell monolayer. (b) The quantitative assay performed in a 96-multiwell plate where 4 sera (I, 2, 3, and 4) containing neutralizing antibody against BVDV were tested at different dilutions in the presence of gE2-I4 (+Sera +E2) and in the absence of gE2-I4 (+Sera -E2). Control virus was established in the absence of sera and presence of gE2-I 4 and in the absence of sera and gE2-14. Crystal violet staining allows macroscopic evaluation of the integrity or the destruction of the cell monolayer. (c) Bar graph showing the quantification of serum neutralization made on the basis of three different experiments $(* *=P<0.001)$. Results are expressed as the log2 of the highest dilution of the serum that inhibited the development of virus-induced cytopathic effect in cell culture. 

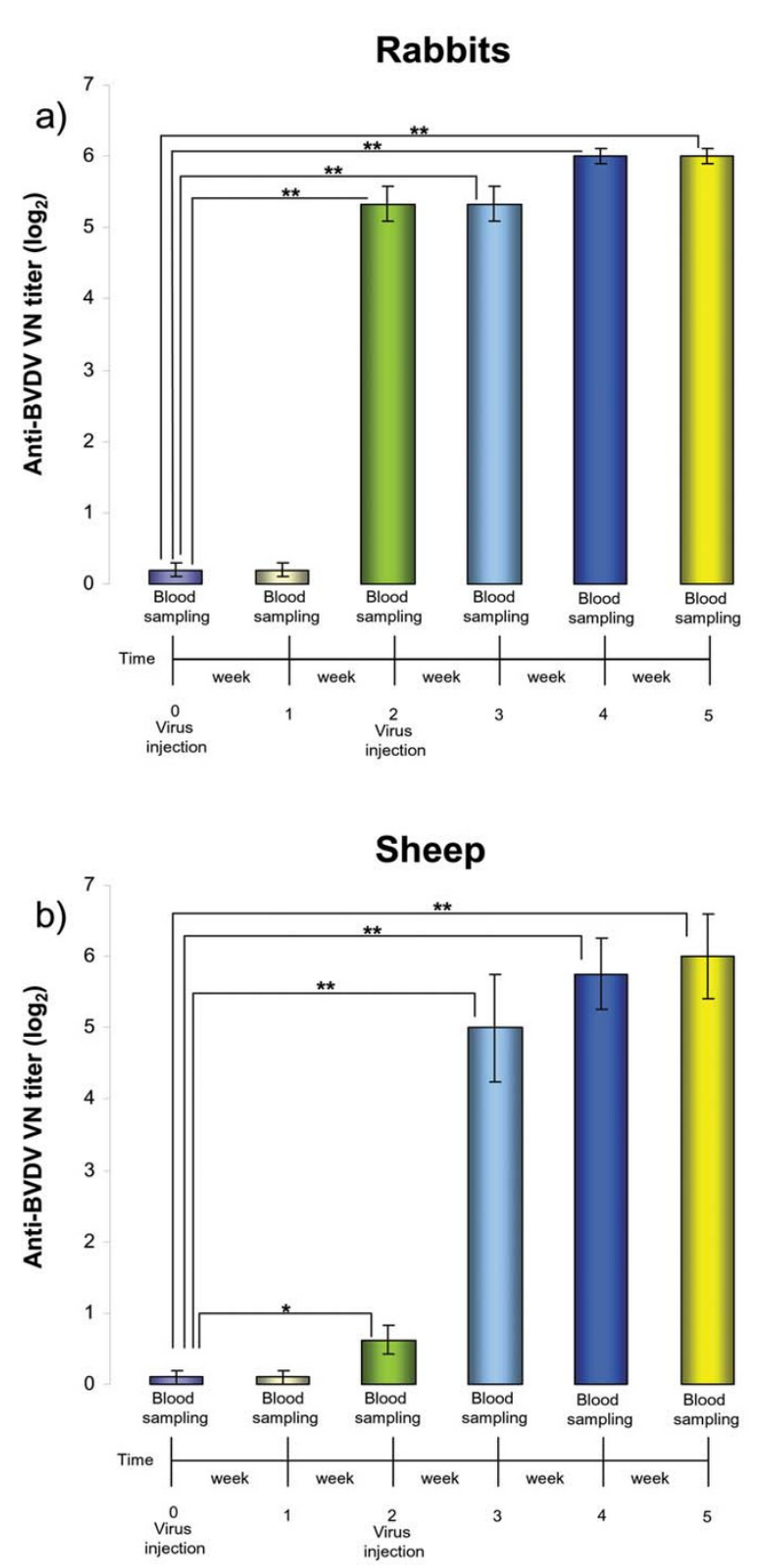

Figure 5

Kinetics of the humoral immune responses of rabbits and sheep immunized with BoHV-4CMV-IgKE2-

I 4 $\Delta$ TK. Sera collected from rabbits (a) and sheep (b) before immunization (time 0 ) and after immunization (time I, 2, 3, 4 and 5) were evaluated for anti-BVD neutralizing antibodies by serum neutralization (SN) test. Serum neutralizing antibodies against BVDV are expressed as the reciprocal of the highest dilution of the serum that inhibited the development of virus-induced CPE in MDBK cells. Virus neutralization (VN) titers of 2 ( $\log 2)$ were considered to be positive. In both panels, each value represents the mean response of 3 rabbits (a) $(* *=P<0.001$, $*=P<0,05)$ or 4 sheep $(\mathrm{b})(* *=$ $P<0.001, *=P<0,05)$. Each test was repeated 3 times and statistical significance was evaluated by Student's $t$ test. humoral immune response against BVDV, in both groups of animals as demonstrated by serum neutralization test (Fig. 5a and 5b).

\section{Discussion and conclusion}

In the present study, the establishment and employment of a recombinant BoHV-4, expressing a secreted form of BVDV gE2, has been described. The gE2 protein plays a major role in virus attachment and entry of BVDV [29]. Furthermore, BVDV gE2 is important for the induction of neutralizing antibodies and protection against BVDV challenge in cattle $[20,30,31]$. In vitro analysis demonstrated that deletion of the transmembrane anchor and addition of a heterologous signal sequence resulted in efficient secretion of gE2 into the culture medium. In contrast, full-length gE2, as well as truncated gE2 without signal sequence, remained entirely cell-associated. Animals immunized with plasmid encoding a secreted form of gE2 developed significantly higher IgG and virus neutralizing antibody titres compared to animals vaccinated with plasmid encoding a membrane linked gE2 [21]. Starting with this data, we successfully engineerized a eukaryotic expression cassette secreting high levels of gE2 into the medium of transfected cells, where the addition of a 14 aa non-structured, highly hydrophilic peptide to the C-terminus, significantly increased gE2 secretion compared to a less hydrophilic 23 aa control peptide. Although this 14 aa peptide was added to increase gE2 secretion, it could be also exploited as a marker to distinguish naturallyinfected from vaccinated animals The next step was to vectorialized the expression cassette into a BoHV-4-based vector clone as BAC. For this purpose, we applied a Recombineering system (recombination -mediated genetic engineering) [32], using three $\lambda$ Red-encoded genes: exo, bet and gam. exo encodes a 5'-3' exonuclease that produces $3^{\prime}$ overhangs from introduced doublestranded DNA targeting cassettes (dsDNA). bet encodes a pairing protein that binds to the 3 ' overhangs and mediates its annealing and homologous recombination with complementary DNA present on the BAC. At the same time, gam encodes an inhibitor of the E. coli RecBCD exonuclease and thereby protects the linear DNA-targeting cassette from degradation by RecBCD. $\lambda$ Red (or the corresponding RecE and RecT genes of the prophage Rac) can be expressed from a multicopy plasmid using an inducible promoter $[33,34]$. Alternatively, these genes can be expressed from a stably integrated defective prophage, where exo, bet and gam are controlled by the strong phage promoter $p \mathrm{~L}$, under stringent control of the temperaturesensitive repressor, cI857[35,36]. In the prophage system, exo, bet and gam are not expressed when the bacteria are kept at $32^{\circ} \mathrm{C}$. By shifting the bacteria to $42^{\circ} \mathrm{C}$ for as little as $15 \mathrm{~min}$, the genes are rapidly induced to very high levels and homologous recombination is very efficient. Based on galK selection [28], which we modified by the 
introduction of a kanamycin resistance expression cassette that drastically improved the background in the first targeting step, we successfully introduced the CMV-IgKE2-14 expression cassette into the BoHV-4 genome. For homologous recombination, we chose the TK gene as a target site because in other herpesviruses, the TK gene inactivation results in drastic attenuation in vivo [23,24]. Viral vectorassociated risk is a major concern in viral vector development, and attenuation is regarded as a desirable feature of a viral vector and efforts are directed toward the development of highly attenuated strains [37]. However, in the case of BoHV-4, the virus naturally exhibits limited or no pathogenicity in both natural and experimental hosts $[8,38,39]$. Therefore, further attenuation by disruption of genes in addition to TK is neither necessary nor desirable. The resulting recombinant, BoHV-4CMV-IgKE2-14 $\Delta \mathrm{TK}$, has a 94 bp TK gene deletion, and the remaining TK gene is interrupted by an CMV-IgKE2-14 expression cassette. Reconstitution of the recombinant virus generated here resulted in a recombinant vector in which robust expression of the BVDV transgene was observed in all infected cell lines tested and immunization of rabbits and sheep with BoHV-4CMV-IgKE2-14 $\Delta$ TK resulted in the induction of neutralizing antibodies against BVDV in the absence of an adjuvant and after a single injection dose.

The use of viruses as vectors for the delivery of heterologous antigens needs careful consideration because the immune system has evolved a sophisticated array of mechanisms to both detect and eliminate invading viruses. A viral vector also delivers the antigen directly into the host cell, which allows for high-level intracellular expression. Hence, the viral vector acts as an adjuvant and as a delivery system. An effective viral vector should present the expressed antigen as an immune target and should remain in the host long enough to stimulate an effective response. One of the major concerns about vaccine vector development is preexisting antivector immunity in the host organism. In the case of BoHV-4, this should not be a problem, because BoHV-4does not naturally elicit the production of serum neutralizingantibodies $[23,24]$.

DNA vaccines, like viral vectored vaccines, are capable of raising both humoral and cellular responses, but, unlike live virus vaccines, they are extremely stable and versatile for manufacture and storage. Themain limitation of DNAbased vaccines remains their low relativeefficacy, requiring multiple boosts with high doses (up to $500 \mu \mathrm{g}$ of plasmid DNA per injection) to generate responses comparable to those achieved from an attenuated virus vaccination $[23,24]$. BoHV-4 is an attractive potential vaccine vector in that it establishes persistent infections in its natural bovine host and in an experimental host like the rabbit $[40,41]$, suggesting that a BoHV-4 vaccine vector would be particularly useful for long-lasting expression of the heterologous antigen. Although BoHV-4 has been demonstrated in many tissues during persistent infection by PCR, in situ hybridization, or recovery of virus after culture explants, the accumulated evidence suggests that one site of persistence in both natural and experimental hosts is cells of the monocyte/macrophage lineage $[6,42]$. This is probably the most attractive feature of BoHV-4 in terms of vaccine vector development. Since macrophages are both professional antigen-presenting cells and natural targets of BoHV-4, the delivered heterologous antigen should be directly processed and presented to the immune system, ultimately leading to an amplification of the immune response after the homing of macrophages persistently infected with BoHV-4 to lymphoid organs like the spleen and lymph nodes. Another feature of BoHV-4 that makes it a potential gene delivery vector is the lack of evidence for oncogenicity. Other gammaherpesviruses like EpsteinBarr virus (EBV), herpesvirus saimiri (HVS), human herpesvirus 8 (HHV-8), and murine gammaherpesvirus-68 (MHV-68) have been associated with the growth-transforming ability [43-45]. In contrast, no evidence for growth-transformation by BoHV-4 has been obtained [26]. Each of the genes associated with transformation by other gammaherpesviruses is unique to each individual virus, and homologs are not found in other transforming gammaherpesviruses or BoHV-4 [26]. Considerable effort has been directed toward the development of the alphaherpesvirus HSV-1 as a vector for gene therapy, especially for the nervous system, because HSV-1 is a human neurotropic virus [37]. A major disadvantage of HSV-1 is its cytotoxicity for many cell types, including neurons, although genetic alterations have been made to reduce its cytotoxicity [37]. In contrast, we have previously shown that BoHV-4 is able to infect a wide variety of cell types, including neural cells and liver cells, without cytotoxicity $[46,47]$. These observations suggest that BoHV-4 might have the potential for use as a gene delivery vector for the nervous system and liver. Due to the dispensability of many genes, herpesvirus genomes should be able to accommodate at least $40 \mathrm{~kb}$ of foreign sequence [37]. This would enable the use of complex regulatory regions, which, in contrast to the simple CMV enhancer-promoter system which was used, should confer high-level, tissuespecific and developmentally stable gene expression. BoHV-4 has a similar size genome to those of other gammaherpesviruses, and it is likely that BoHV-4 could carry significant amounts of heterologous genetic information. Like other gammaherpesvirus genomes, the BoHV-4 genome is established in an episomal state in persistently infected cells [48]. Integration of the BoHV-4 genome into the host cell genome is therefore not necessary for maintenance. Recombinant BoHV-4 could theoretically combine the efficiency of a viral delivery system with that of an artificial chromosome, thus alleviating the influence 
on gene expression of the position of integration into the host genome.

In the present study BoHV-4CMV-IgKE2-14ATK has been shown to be effective in eliciting the humoral immune response in rabbits and sheep, without any clinical signs, suggesting the possibility to use BoHV-4 based vector for vaccination of animal species different from the natural bovine host. Although the efficacy of a BoHV-4-vectored vaccine for BVDV needs to be corroborated by an in vivo challenge study with a pathogenic BVDV in their natural host, the results we obtained in the rabbit and sheep are extremely encouraging.

\section{Methods \\ Plasmid constructs}

Full length gE2 remains cell associated; a plasmid construct, pCMV-IgKE2-14, was made that encodes a secreted form lacking the putative transmembrane domain of $\mathrm{gE} 2$, with pSecTag2HygroA (Invitrogen) as a backbone, and containing the cytomegalovirus (CMV) promoter and an immunoglobulin $K$ light chain (Igk) leader sequence specifying secretion of heterologous proteins. Total RNA from BVDV strain NADL-infected Madin-Darby bovine kidney (MDBK) cells was reverse transcribed using the TPrimed first-strand kit (Amersham Biosciences). Three microliters of reverse transcribed RNA were amplified with a primer pair including an HindIII restriction site in the $5^{\prime}$ end (underlined) (sense primer, 5'-CCC GA AGC TTG CAC TTG GAT TGC AAA CCT GAA TTC-3') in frame with the Igk signal peptide of the plasmid backbone and an XhoI restriction sitein the $3^{\prime}$ end (underlined) (antisense, 5'-CCC CGC TC GAG AGT GGA CTC AGC GAA GTA ATC CCG-3') in frame with a polar non structured 14-amino-acid peptide of the plasmid backbone. In order to obtain pIgKE2-23, the NheI/XhoI fragment from pIgKE2-14 was sub-cloned into the NheI/Xhol sites of pEGFP-C1 depleted of EGFP. This construct possesses an extra 23aa in the $\mathrm{C}$ terminal of $\mathrm{gE2}$, belonging to the multi cloning site of the vector.

The first targeting vector, pTK-KanaGalK-TK, was generated by sub-cloning the galactokinase prokaryotic expression cassette (GalK), along with the kanamycin resistant expression cassette, into the pINT2 shuttle vector [25]. GalK was excised out from pGalK [28] with BamHI/EcoRI, blunted end with T4 polymerase (Roche) and ligated with T4 ligase into pINT2 cut with SmaI and dephosphatated with Shrimp Alkaline Phosphatase (Roche). A Kanamycin expression cassette was then cut out with MluI from pMuKana vector [47], blunted end and ligated into PINT2GalK cut with PstI and blunted end, so that the pTK-KanaGalKTK was generated.
The second Targeting Vector, pTK-CMV-IgKE2-14-TK, was generated by sub-cloning the CMV-IgKE2-14 expression cassette into pINT2GFP (Donofrio et al., 2002). CMVIgKE2-14 was excise out from pIgKE2-14 with SalI and ligated into pINT2GFP cut with SalI to deplete the CMVGFP cassette.

\section{Recombineering and selection}

Recombineering was performed as previously described (Warming et al., 2005) with some modifications. Five hundreds $\mu \mathrm{l}$ of a $32^{\circ} \mathrm{C}$ overnight culture of SW102 [28] containing BAC-BoHV-4 [27], were diluted in $25 \mathrm{ml}$ Luria-Bertani (LB) medium with or without chloramphenicol (SIGMA) selection $(12.5 \mu \mathrm{g} / \mathrm{ml})$ in a $50 \mathrm{ml}$ baffled conical flask and grown at $32^{\circ} \mathrm{C}$ in a shaking water bath to an $\mathrm{OD}_{600}$ of 0.6 . Then, $10 \mathrm{ml}$ was transferred to another baffled $50 \mathrm{ml}$ conical flask and heat-shocked at $42^{\circ} \mathrm{C}$ for exactly $15 \mathrm{~min}$ in a shaking water bath. The remaining culture was left at $32^{\circ} \mathrm{C}$ as the uninduced control. After 15 min the two samples, induced and uninduced, were briefly cooled in ice/water bath slurry and then transferred to two $15 \mathrm{ml}$ Falcon tubes and pelleted using 5000 r.p.m. (eppendorf centrifuge) at $0^{\circ} \mathrm{C}$ for 5 min. The supernatant was poured off and the pellet was resuspended in $1 \mathrm{ml}$ ice-cold $\mathrm{ddH}_{2} \mathrm{O}$ by gently swirling the tubes in ice/water bath slurry. Subsequently, $9 \mathrm{ml}$ icecold $\mathrm{ddH}_{2} \mathrm{O}$ was added and the samples pelleted again. This step was repeated once more, the supernatant was removed and the pellet (50 $\mu \mathrm{l}$ each) was kept on ice until electroporated with gel-purified $\sim 4.3 \mathrm{~kb}$ fragment (TKKanaGalK-TK) obtained by cutting pTK-KanaGalK-TK with Xhol/EcoRI (ROCHE). An aliquot of $25 \mu \mathrm{l}$ was used for each electroporation in a $0.1 \mathrm{~cm}$ cuvette at $25 \mu \mathrm{F}, 2.5$ $\mathrm{kV}$ and $201 \Omega$. After electroporation, the bacteria were recovered in $1 \mathrm{ml} \mathrm{LB}\left(15 \mathrm{ml}\right.$ Falcon tube) for $1 \mathrm{~h}$ in a $32^{\circ} \mathrm{C}$ shaking water bath. For the counter selection step (see below), the bacteria were recovered in $10 \mathrm{ml} \mathrm{LB}$ in a $50 \mathrm{ml}$ baffled conical flask and incubated for $4.5 \mathrm{~h}$ in a $32^{\circ} \mathrm{C}$ shaking water bath.

After the recovery period, the bacteria were washed twice in sterile $1 \times \mathrm{M} 9$ salts $\left(6 \mathrm{~g} / \mathrm{l} \mathrm{Na}_{2} \mathrm{HPO}_{4}, 3 \mathrm{~g} / \mathrm{l} \mathrm{K \textrm {K } _ { 2 }} \mathrm{PO}_{4}, 1 \mathrm{~g} / \mathrm{l}\right.$ $\mathrm{NH}_{4} \mathrm{Cl}$ and $0.5 \mathrm{~g} / \mathrm{l} \mathrm{NaCl}$ ) (SIGMA) as follows: $1 \mathrm{ml}$ culture was pelleted in an eppendorf tube at 13,200 r.p.m. for $15 \mathrm{"} \mathrm{and} \mathrm{the} \mathrm{supernatant} \mathrm{was} \mathrm{removed} \mathrm{with} \mathrm{a} \mathrm{pipette.} \mathrm{The}$ pellet was resuspended in $1 \mathrm{ml}$ of $1 \times \mathrm{M} 9$ salts, and pelleted again. This washing step was repeated once more. After the second wash, the supernatant was removed and the pellet was resuspended in $1 \mathrm{ml}$ of $1 \times \mathrm{M} 9$ salts before plating serial dilutions $(100 \mu \mathrm{l}$ each of 1:10, 1:100 and 1:1000 dilutions) on M63 minimal medium plates (agar $15 \mathrm{~g} / \mathrm{l}$; (DIFCO, BD Biosciences), 0.2\% D-galactose (SIGMA), 1 $\mathrm{mg} / \mathrm{l} \mathrm{D}$-biotin (SIGMA), $45 \mathrm{mg} / \mathrm{l} \mathrm{L}$-leucine (SIGMA) and $50 \mathrm{mg} / \mathrm{l} \mathrm{kanamycin}$ (SIGMA)). Washing in M9 salts is necessary to remove any rich media from the bacteria prior to 
selection on minimal medium plates. Plates were incubated 3-5 days at $32^{\circ} \mathrm{C}$. Several selected colonies were picked up, streaked on McConkey agar indicator plates (DIFCO, BD Biosciences) containing $50 \mu \mathrm{g} / \mathrm{ml}$ of kanamycin and incubated at $32{ }^{\circ} \mathrm{C}$ for 3 days until red colonies appeared. Red colonies were grown over night in $5 \mathrm{ml}$ of LB containing $50 \mu \mathrm{g} / \mathrm{ml}$ of kanamycin an BAC-BoHV-4 was purified and analyzed through HindIII restriction enzyme digestion for TK-KanaGalK-TK fragment targeted integration into the BoHV-4 TK locus.

SW102 bacteria containing KanaGalK targeted BACBoHV-4 genome were grown, heat induced as described above and electroporated with a gel purified $\sim 4.2 \mathrm{~kb}$ fragment (TK-CMV-IgKE2-14-TK) obtained by cutting pTKCMV-IgKE2-14-TK with PvuII/ClaI (ROCHE). For the counter selection step, the bacteria were recovered in 10 $\mathrm{ml} \mathrm{LB}$ in a $50 \mathrm{ml}$ baffled conical flask and incubated for $4.5 \mathrm{~h}$ in a $32^{\circ} \mathrm{C}$ shaking water bath. Bacteria serial dilutions were plated on M63 minimal medium plates containing $15 \mathrm{~g} / \mathrm{l}$ agar, $0.2 \%$ glycerol (SIGMA), $1 \mathrm{mg} / \mathrm{l} \mathrm{D}-$ biotin, $45 \mathrm{mg} / \mathrm{l} \mathrm{L}$-leucine, $0.2 \%$ 2-deoxy-galactose (DOG, SSIGMA) and $12.5 \mu \mathrm{g} / \mathrm{ml}$ chloramphenicol. Plates were incubated 3-5 days at $32{ }^{\circ} \mathrm{C}$. Several selected colonies were picked up, streaked on McConkey agar indicator plates (DIFCO, BD Biosciences) containing $12.5 \mu \mathrm{g} / \mathrm{ml}$ of chloramphenicol and incubated at $32^{\circ} \mathrm{C}$ for 3 days until white colonies appeared. White colonies were grown in duplicate for 5-8 hours in $1 \mathrm{ml}$ of LB containing $50 \mu \mathrm{g} / \mathrm{ml}$ of kanamycin or LB containing $12.5 \mu \mathrm{g} / \mathrm{ml}$ of chloramphenicol. Only those colonies growing on chloramphenicol and not on kanamycin were kept and grown over night in $5 \mathrm{ml}$ of LB containing $12.5 \mu \mathrm{g} / \mathrm{ml}$ of chloramphenicol. BAC-BoHV-4 was purified and analyze through HindIII restriction enzyme digestion for pTK-CMV-IgKE2-14-TK fragment targeted integration. Original detailed protocols for recombineering can also be found at the recombineering website [49].

\section{Viruses}

Recombinant BoHV-4 (BoHV-4CMV-IgKE2-14ATK), and wild type BVDV (strain NADL) were propagated by infecting confluent monolayers of MDBK cells at a multiplicity of infection (m.o.i.) of $0.550 \%$ tissue culture infectious doses (TCID50) per cell and maintained in minimal essential medium (MEM) (SIGMA) with $2 \%$ fetal bovine serum (FBS) for $2 \mathrm{~h}$. The medium was then removed and replaced by fresh MEM containing 10\% FBS. When approximately $90 \%$ of the cell monolayer exhibited cytopathic effect (CPE) (approximately $72 \mathrm{~h}$ post infection), the virus was prepared by freezing and thawing cells three times and pelleting the virions through $30 \%$ sucrose, as described previously [46]. Virus pellets were resuspended in cold MEM without FBS. TCID50 were determined with MDBK cells by limiting dilution.

\section{Cell cultures}

Human rhabdomyosarcoma ((RD-4) ATCC CCL-136), MDBK (ATCC, CCL-22), bovine embryo kidney ((BEL) from M. Ferrari Istituto Zooprofilattico, Brescia, Italy), bovine embryo lung ((BEL) from M. Ferrari Istituto Zooprofilattico, Brescia, Italy) and bovine macrophage ((BoMac) from V. van Santen, Auburn University, USA) cell lines were cultured in Dulbecco's modified essential medium (DMEM) (SIGMA) containing 10\% FBS, 2 mM Lglutamine, $100 \mathrm{IU} / \mathrm{ml}$ penicillin (SIGMA), and $100 \mu \mathrm{g} / \mathrm{ml}$ streptomycin (SIGMA). Primary bovine endometrial cells, stromal and epithelial (BEND), were obtained from $\mathrm{M}$. Sheldon (University of London, UK) and kept in RPMI1640 (SIGMA) containing 10\% FBS, $50 \mathrm{IU} / \mathrm{ml}$ of penicillin, $50 \mu \mathrm{g} / \mathrm{ml}$ of streptomycin and $2.5 \mu \mathrm{g} / \mathrm{ml}$ of Amphotericin B.

\section{Cell culture electroporation and recombinant virus preparation}

MDBK and BEK cells were maintained as a monolayer with growth medium containing 90\% DMEM, 10\% FBS, $2 \mathrm{mM}$ L-glutamine, $100 \mathrm{IU} / \mathrm{ml}$ penicillin and $10 \mu \mathrm{g} / \mathrm{ml}$ streptomycin. Cells were sub cultured to a fresh culture vessel when growth reached 70 to $90 \%$ confluence (i.e., every 3 to 5 days) and were incubated at $37^{\circ} \mathrm{C}$ in a humidified atmosphere of $95 \%$ air-5\% CO2. Plasmid DNA (5 $\mu \mathrm{g})$ in $500 \mu \mathrm{l}$ DMEM without serum was electroporated (Equibio apparatus, $270 \mathrm{~V}, 960 \mu \mathrm{F}, 4-\mathrm{mm}$ gap cuvettes) into BEK cells from a confluent $25-\mathrm{cm} 2$ flask. Electroporated cells were returned to the flask, fed the next day, and split 1:2 when they reached confluence at 2 days post electroporation. Cells were left to grow until CPE appeared. Recombinant viruses were propagated by infecting confluent monolayers of MDBK cells at an m.o.i. of 0.5 TCID50 per cell and maintaining them in MEM with $10 \%$ FBS for $2 \mathrm{~h}$. The medium was then removed and replaced by fresh MEM containing 10\% FBS. When approximately $90 \%$ of the cell monolayer exhibited CPE (approximately $72 \mathrm{~h}$ post infection), the virus was prepared by freezing and thawing cells three times and pelleting virions through $30 \%$ sucrose, as previously described [46]. Virus pellets were resuspended in cold MEM without FBS. TCID50 were determined on MDBK cells by limiting dilution.

\section{Bovine macrophage cell line persistently infected with BoHV-4CMV-IgKE2-I4ATK (BoMac/BoHV-4CMV-IgKE2- I4 $\triangle T K$ )}

BoMac/BoHV-4CMV-IgKE2-14 $\Delta$ TK cells were established as previously described [50] by infecting BoMac cells, a cell line established from peritoneal macrophages by transformation with simian virus 40 DNA [51]. Confluent monolayers of BoMac cells were inoculated at an m.o.i. of 1 TCID50 per cell with recombinant BoHV-4CMV-IgKE2$14 \Delta \mathrm{TK}$. By the third day after inoculation, more than $95 \%$ of cells had detached from the monolayer, leaving behind 
a small number of cells that did not exhibit CPE. Confluent monolayers established from survivingcells showed $100 \%$ infection, as indicated by the strong fluorescentsignal, but without apparent signs of CPE. Also consistent with our previous observations [50], the persistently infected macrophages produced infectious BoHV-4CMVIgKE2-14 $\Delta$ TK and secreted gE2 (in results). BoMac/BoHV4CMV-IgKE2-14 $\Delta$ TK cells were sub cultured at a dilution of $1: 2$ every 3 days.

\section{Western immunoblotting}

Cell extracts containing $50 \mu \mathrm{g}$ of total protein were electrophoresed through 12\% SDS-polyacrylamide gels and transferred to nylon membranes by electro blotting. Membranes were incubated with monoclonal anti-BVDV-gE2 antibody (clone 157; VRMD, Inc., Pullman, WA), probed with horseradish peroxidase-labeled anti-mouse immunoglobulin antibody (SIGMA), and visualized by enhanced chemiluminescence (ECL Kit; PIERCE, Rockford, IL).

\section{Serological tests}

Serum neutralization tests were performed as follows. Twenty five microliters of each serum sample was added to the first line of wells of 96-well plates. Twenty-five microliters of DMEM were added to each well and, for each serum tested, serial twofold dilutions were made. Positive and negative serum controls were included. Twenty-five microliters of virus suspension containing 100 TCID50 of BVDV were added to each well. After $1 \mathrm{~h}$ of incubation at $37^{\circ} \mathrm{C}, 50 \mu \mathrm{l}$ of a MDBK cell suspension was added to each well and the plates were incubated for 3 days at $37^{\circ} \mathrm{C}$. Expression of viral infectivity and serum neutralizing activity through CPE were detected by microscopy and or by crystal violet staining of the cell monolayer. The neutralization antibody titers were expressed as the reciprocal of the final dilution of serum that completely inhibited viral infectivity.

\section{Animal handling and care}

Rabbits and sheep were cared for and used in accordance with Italian laws for animal experimentation. Rabbits and sheep were maintained at $24^{\circ} \mathrm{C}$ with a controlled light cycle (12 h of light, starting at 6:00 a.m.) and with food and water ad libitum. Blood samples were obtained and viral injections were performed via the auricular vein for the rabbits and via jugular vein for the sheep at scheduled intervals.

\section{Authors' contributions}

GD conceived, designed, performed the experiments and wrote the paper. CS and LR performed the experiments. ST technically contributed. AV and LG provided reagents. SC and CFF intellectually contributed. All authors read and approved the final manuscript.

\section{Acknowledgements}

we would like to thank Professor N. Copeland for providing SWI02 cells, Laura Helen Kramer for English editing and Italian Ministry of University and Scientific Research (Italian National Grant MIUR, PRIN 2005,

2005078885) for financial support.

\section{References}

I. Storz J, Ehlers B, Todd W], Ludwig H: Bovine Cytomegaloviruses: Identification and Differential Properties. J Gen Virol 1984, 65:697-706.

2. Bartha $A$, Juhasz $M$, Liebermann $\mathrm{H}$ : Isolation of a bovine herpesvirus from calves with respiratory disease and keratoconjunctivitis. A preliminary report. Acta Vet Acad Sci Hung 1966 , 16:357-358.

3. Mohanty SB, Hammond RC, Lillie MG: A new bovine herpesvirus and its effect on experimentally infected calves. Brief report. Arch Gesamte Virusforsch 197I, 33:394-395.

4. Dubuisson J, Thiry E, Thalasso F, Bublot M, Pastoret PP: Biological and biochemical comparison of bovid herpesvirus-4 strains. Vet Microbiol 1988, 16:339-349.

5. Ludwig H: Bovine herpersviruses. In The herpesviruses Volume 2. Edited by: Roizman B. New York, N.Y., Plenum Press; 1983:I35-2 14.

6. Osorio FA, Rock DL, Reed DE: Studies on the pathogenesis of a bovine cytomegalo-like virus in an experimental host. J Gen Virol 1985, 66 ( Pt 9): |94|-|95|

7. Donofrio G, Martignani E, Sartori C, Vanderplasschen A, Cavirani S, Flammini CF, Gillet L: Generation of a transposon insertion mutant library for bovine herpesvirus 4 cloned as a bacterial artificial chromosome by in vitro MuA based DNA transposition system. I Virol Methods 2007, I 4I:63-70.

8. Thiry E, Bublot M, Dubuisson J, Pastoret PP: Bovine herpesvirus-4 (BHV-4) infection in cattle. In Herpesvirus diseases of cattle, horses and pigs Edited by: G. W. Boston, Mass, Kluwer; 1989:96-I I5.

9. Bublot M, Lomonte P, Lequarre AS, Albrecht JC, Nicholas J, Fleckenstein B, Pastoret PP, Thiry E: Genetic relationships between bovine herpesvirus 4 and the gammaherpesviruses EpsteinBarr virus and herpesvirus saimiri. Virology 1992, 190:654-665.

10. Ehlers B, Buhk HJ, Ludwig H: Analysis of bovine cytomegalovirus genome structure: cloning and mapping of the monomeric polyrepetitive DNA unit, and comparison of European and American strains. J Gen Virol 1985, 66 ( Pt I):55-68.

II. Zimmermann W, Broll H, Ehlers B, Buhk HJ, Rosenthal A, Goltz M: Genome sequence of bovine herpesvirus 4 , a bovine Rhadinovirus, and identification of an origin of DNA replication. J Virol 200I, 75: I I86-I I94.

12. Peterson RB, Goyal SM: Propagation and quantitation of animal herpesviruses in eight cell culture systems. Comp Immunol Microbiol Infect Dis 1988, I 1:93-98.

13. Wyler R, Engels M, Schwyzer M: Infectious bovine rhinotracheitis/vulvo-vaginitis (BHV-I). In Herpesvirus diseases of cattle, horses and pigs Edited by: G. W. Boston, Mass, Kluwer; 1989:1-72.

14. Egyed L, Bartha A: PCR studies on the potential sites for latency of BHV-4 in calves. Vet Res Commun 1998, 22:209-216.

15. Bolin SR: Immunogens of bovine viral diarrhea virus. Vet Microbiol 1993, 37:263-27|.

16. Becher P, Konig M, Paton DJ, Thiel HJ: Further characterization of border disease virus isolates: evidence for the presence of more than three species within the genus pestivirus. Virology 1995, 209:200-206.

17. Becher P, Shannon AD, Tautz N, Thiel HJ: Molecular characterization of border disease virus, a pestivirus from sheep. Virology 1994, 198:542-55I.

18. Thiel HJ, Stark R, Weiland E, Rumenapf T, Meyers G: Hog cholera virus: molecular composition of virions from a pestivirus. J Virol 199I, 65:4705-47I2

19. Thiel HJ, Plagemann PGW, Moennig V: Pestiviruses. In Virology 3th edition. Edited by: B. N. Fields DMKPMH. Philadelphia, Pa, LippincottRaven Publishers; 1996: 1059-1073.

20. Rumenapf T, Unger G, Strauss JH, Thiel HJ: Processing of the envelope glycoproteins of pestiviruses. J Virol 1993, 67:3288-3294.

21. Liang R, van den Hurk JV, Zheng C, Yu H, Pontarollo RA, Babiuk LA, van Drunen Littel-van den Hurk S: Immunization with plasmid DNA encoding a truncated, secreted form of the bovine viral 
diarrhea virus E2 protein elicits strong humoral and cellular immune responses. Vaccine 2005, 23:5252-5262.

22. Schnitzlein WM, Winans R, Ellsworth S, Tripathy DN: Generation of thymidine kinase-deficient mutants of infectious laryngotracheitis virus. Virology 1995, 209:304-3I4.

23. Kit S, Qavi H, Gaines JD, Billingsley P, McConnell S: Thymidine kinase-negative bovine herpesvirus type I mutant is stable and highly attenuated in calves. Arch Virol 1985, 86:63-83.

24. McGregor S, Easterday BC, Kaplan AS, Ben-Porat T: Vaccination of swine with thymidine kinase-deficient mutants of pseudorabies virus. Am J Vet Res 1985, 46:1494- 1497.

25. Donofrio G, Cavirani S, Simone T, van Santen VL: Potential of bovine herpesvirus $\mathbf{4}$ as a gene delivery vector. J Virol Methods 2002, 101:49-61.

26. Lomonte P, Bublot M, van Santen V, Keil G, Pastoret PP, Thiry E: Bovine herpesvirus 4: genomic organization and relationship with two other gammaherpesviruses, Epstein-Barr virus and herpesvirus saimiri. Vet Microbiol 1996, 53:79-89.

27. Gillet L, Daix V, Donofrio G, Wagner M, Koszinowski UH, China B, Ackermann M, Markine-Goriaynoff N, Vanderplasschen A: Development of bovine herpesvirus 4 as an expression vector using bacterial artificial chromosome cloning. J Gen Virol 2005, 86:907-917.

28. Warming S, Costantino N, Court DL, Jenkins NA, Copeland NG: Simple and highly efficient BAC recombineering using galK selection. Nucleic Acids Res 2005, 33:

29. Donis RO: Molecular biology of bovine viral diarrhea virus and its interactions with the host. Vet Clin North Am Food Anim Pract 1995, II:393-423.

30. Harpin S, Hurley DJ, Mbikay M, Talbot B, Elazhary Y: Vaccination of cattle with a DNA plasmid encoding the bovine viral diarrhoea virus major glycoprotein E2. J Gen Virol 1999, 80:3|37-3|44

31. Meyers G, Rumenapf T, Thiel HJ: Molecular cloning and nucleotide sequence of the genome of hog cholera virus. Virology 1989, I 71:555-567.

32. Copeland NG, Jenkins NA, Court DL: Recombineering: a powerful new tool for mouse functional genomics. Nat Rev Genet 200I, 2:769-779.

33. Zhang Y, Buchholz F, Muyrers JP, Stewart AF: A new logic for DNA engineering using recombination in Escherichia coli. Nat Genet 1998, 20:123-128.

34. Muyrers JP, Zhang Y, Testa G, Stewart AF: Rapid modification of bacterial artificial chromosomes by ET-recombination. Nucleic Acids Res 1999, 27:1555-1557.

35. Yu D, Ellis HM, Lee EC, Jenkins NA, Copeland NG, Court DL: An efficient recombination system for chromosome engineering in Escherichia coli. Proc Natl Acad Sci U S A 2000 97:5978-5983.

36. Lee EC, Yu D, Martinez de Velasco J, Tessarollo L, Swing DA, Court DL, Jenkins NA, Copeland NG: A highly efficient Escherichia coli-based chromosome engineering system adapted for recombinogenic targeting and subcloning of BAC DNA. Genomics 200I, 73:56-65.

37. Glorioso JC, DeLuca NA, Fink DJ: Development and application of herpes simplex virus vectors for human gene therapy. Annu Rev Microbiol 1995, 49:675-7IO.

38. Wellemans G, Van Opdenbosch E, Mammerickx M: [Experimental inoculation of bovine herpesvirus 4 (strain LVR I 40) in pregnant and nonpregnant cows]. Ann Rech Vet 1986, 17:89-94.

39. Castrucci G, Frigeri F, Ferrari M, Ranucci S, Aldrovandi V, Cilli V, Rampichini L, Gatti R: Experimental infection of calves with strains of Bovid herpesvirus-4. Comp Immunol Microbiol Infect Dis 1987, 10:41-49.

40. Dubuisson J, Thiry E, Bublot M, Thomas I, van Bressem MF, Coignoul F, Pastoret PP: Experimental infection of bulls with a genital isolate of bovine herpesvirus-4 and reactivation of latent virus with dexamethasone. Vet Microbiol 1989, 21:97-91 I4.

4I. Osorio FA, Reed DE, Rock DL: Experimental infection of rabbits with bovine herpesvirus-4: acute and persistent infection. Vet Microbiol I982, 7:503-5।3.

42. Osorio FA, Reed DE: Experimental inoculation of cattle with bovine herpesvirus-4: evidence for a lymphoid-associated persistent infection. Am J Vet Res 1983, 44:975-980.
43. Jung JU, Choi JK, Ensser A, Biesinger B: Herpesvirus saimiri as a model for gammaherpesvirus oncogenesis. Semin Cancer Biol 1999, 9:231-239.

44. Moore PS, Chang Y: Kaposi's sarcoma-associated herpesvirusencoded oncogenes and oncogenesis. J Natl Cancer Inst Monogr 1998:65-71.

45. Moses AV, Fish KN, Ruhl R, Smith PP, Strussenberg JG, Zhu L, Chandran B, Nelson JA: Long-Term Infection and Transformation of Dermal Microvascular Endothelial Cells by Human Herpesvirus 8. J Virol 1999, 73:6892-6902.

46. Donofrio G, Cavaggioni A, Bondi M, Cavirani S, Flammini CF, Mucignat-Caretta C: Outcome of bovine herpesvirus 4 infection following direct viral injection in the lateral ventricle of the mouse brain. Microbes Infect 2006, 8:898-904.

47. Donofrio G, Cavirani S, Vanderplasschen A, Gillet L, Flammini CF: Recombinant bovine herpesvirus 4 (BoHV-4) expressing glycoprotein D of BoHV-I is immunogenic and elicits serumneutralizing antibodies against BoHV-I in a rabbit model. Clin Vaccine Immunol 2006, I 3: I 246-I 254.

48. Donofrio G, Cavirani S, van Santen VL: Establishment of a cell line persistently infected with bovine herpesvirus- 4 by use of a recombinant virus. J Gen Virol 2000, 81 :1807-18|4.

49. Recombineering: NCl-Frederick. [http://recombineer ing.ncifcrf.gov].

50. Donofrio G, van Santen VL: A bovine macrophage cell line supports bovine herpesvirus-4 persistent infection. I Gen Virol 200I, 82: II8I-II85.

5I. Stabel JR, Stabel TJ: Immortalization and characterization of bovine peritoneal macrophages transfected with SV40 plasmid DNA. Vet Immunol Immunopathol 1995, 45:2 I I-220.
Publish with Bio Med Central and every scientist can read your work free of charge

"BioMed Central will be the most significant development for disseminating the results of biomedical research in our lifetime. "

Sir Paul Nurse, Cancer Research UK

Your research papers will be:

- available free of charge to the entire biomedical community

- peer reviewed and published immediately upon acceptance

- cited in PubMed and archived on PubMed Central

- yours - you keep the copyright

Submit your manuscript here:

http://www.biomedcentral.com/info/publishing_adv.asp
BioMedcentral 